\title{
Molecular biomarker responses in the freshwater mussel Anodonta anatina exposed to an industrial wastewater effluent
}

\author{
Gustaf MO Ekelund Ugge ${ }^{1,2}$ (D) Annie Jonsson ${ }^{2} \cdot$ Olof Berglund $^{1}$
}

Received: 13 April 2021 / Accepted: 21 July 2021 / Published online: 7 August 2021

(C) The Author(s) 2021, corrected publication 2021

\begin{abstract}
Using a selection of molecular biomarkers, we evaluated responses in freshwater mussels (Anodonta anatina) exposed to effluent from an industrial wastewater treatment facility. The aims of this work were to (1) assess biomarkers of general toxicity under sublethal exposure to an anthropogenic mixture of chemicals, represented by an arbitrary effluent, and (2) evaluate the potential of A. anatina as a bioindicator of pollution. Adult mussels ( $n=$ in total 32; 24 males and 8 females) were exposed (96 h) in the laboratory to a fixed dilution of effluent or to a control treatment of standardized freshwater. Metal concentrations were in general higher in the effluent, by an order of magnitude or more, compared to the control. Toxic unit estimates were used as proxies of chemical stress, and $\mathrm{Cu}, \mathrm{Ni}$, and $\mathrm{Zn}$ were identified as potential major contributors $(\mathrm{Cu}>\mathrm{Ni}>\mathrm{Zn})$. Six transcriptional (cat, gst, $h s p 70, h s p 90, m t, s o d)$ and two biochemical (AChE, GST) biomarkers were analyzed in two tissues, gills, and digestive glands. Out of the 16 responses (eight biomarkers $\times$ two tissues), 14 effect sizes were small (within $\pm 28 \%$ of control) and differences non-significant $(p>0.05)$. Results did however show that (1) AChE activity increased by $40 \%$ in gills of exposed mussels compared to control, (2) hsp 90 expression was $100 \%$ higher in exposed female gills compared to control, and (3) three marker signals (AChE in both tissues, and $h s p 70$ in gills) differed between sexes, independent of treatment. Results highlight a need for further investigation of molecular biomarker variability and robustness in A. anatina.
\end{abstract}

Keywords Bivalve $\cdot$ Effect size $\cdot$ Mixture toxicity $\cdot$ RT-qPCR $\cdot$ Sex effects $\cdot$ Wastewater

\section{Introduction}

Chemically complex pollution from anthropogenic activities is a major concern in environmental protection and has gained considerable attention in ecotoxicology and environmental sciences. As a result of daily use in human activities, for instance, agriculture, industrial production, and use of, e.g., pharmaceuticals and personal care products, a variety of natural and synthetic compounds may eventually enter the environment (Anliker et al. 2020; Herrero-Hernández et al. 2020;

Responsible Editor: Bruno Nunes

Gustaf MO Ekelund Ugge

gustaf.ekelund_ugge@biol.lu.se

1 Department of Biology, Lund University, Sölvegatan 37, 223 62 Lund, Sweden

2 School of Bioscience, University of Skövde, Högskolevägen 3, 541 46 Skövde, Sweden
Su et al. 2020; Vareda et al. 2019). Industries and households, via wastewater effluents or runoff, constitute major sources of complex pollution to aquatic recipients (Chen et al. 2020; Ellis and Butler 2015; López-Pacheco et al. 2019). Although separate pollutants in, e.g., treated wastewater often occur at low concentrations (Farkas et al. 2020; Vareda et al. 2019; Wang et al. 2018), they may interact and contribute to additive or synergistic biological effects when in mixtures, causing adverse effects in exposed organisms (Aronzon et al. 2020; Cedergreen 2014; Mebane et al. 2020; Wang et al. 2019). Therefore, in anthropogenic mixtures, such as wastewater effluents, with few conspicuous chemical parameters or without prior knowledge of the chemical composition, general biomarkers of chemical stress might be useful for detection of sublethal mixture toxicity. Furthermore, early biomarker responses can potentially be used under both laboratory and field settings to anticipate harmful effects from pollutant exposure and may, in the long term, improve strategies of monitoring of sensitive ecosystems and protection of recipients (e.g., van der Oost et al. 2003). 
Potential responses in organisms under toxic exposures include changes in molecular parameters, such as enzyme activity or transcript levels, some of which are commonly used as biomarkers to detect general chemical stress (Lehtonen et al. 2016; Perić and Burić 2019; Tsangaris et al. 2016). By definition, biomarkers are used to detect deviations from a normal state (e.g., van der Oost et al. 2003), which is often defined by a control group. However, there is a lack of data describing variabilities in responses and baseline signals, making it difficult to distinguish stress responses from background noise, i.e., normal variation. For molecular markers, it is often unclear how response magnitudes (i.e., effect sizes) vary with interacting internal (e.g., tissue, sex) and external factors (for instance, chemical composition, toxicant concentration, exposure time) (e.g., Bahamonde et al. 2016).

In this study, we assessed biochemical and transcriptional responses that represent commonly used biomarkers of general toxicity and chemical stress. For instance, the enzyme acetylcholinesterase (AChE) is involved in neurosignaling, and its activity in bivalves may respond to different types of mixture exposures (e.g., Aguirre-Martínez and Martín-Díaz 2020; Perić and Burić 2019; Tsangaris et al. 2016). Heat shock proteins protect cellular integrity and respond to a wide range of both chemical and physical stressors (Ferreira-Rodríguez et al. 2018; Liu et al. 2014, 2016). Catalase (CAT) and superoxide dismutase (SOD) protect against oxidative stress, and their activities as well as transcript levels may respond to mixture exposure (Bigot et al. 2011; Gonzalez-Rey et al. 2014; Lehtonen et al. 2016; Turja et al. 2013). Metallothionein (MT) is involved in maintaining cellular metal homeostasis and responds to various metal stressors (Bigot et al. 2011; Mourgaud et al. 2002), and glutathione-S-transferase (GST) is an enzyme important in toxicant metabolism and detoxification, responding to various stressors and mixtures (Bigot et al. 2011; Lehtonen et al. 2016; Perić and Burić 2019; Turja et al. 2013). Using the freshwater duck mussel (Anodonta anatina), we measured enzyme activities of AChE and GST, while cat, gst, heat shock protein 70 ( $h s p 70$ ), heat shock protein 90 ( $h s p 90), m t$, and sod were measured on the transcriptional level.

A. anatina is native to and widely distributed in Scandinavian and many European freshwater ecosystems (LopesLima 2014). Bivalves are likely exposed to toxicants occurring in their (natural or laboratory) environment due to sessility and filtration feeding, and A. anatina could serve as an ecologically relevant freshwater model in ecotoxicology. Previous studies cover, e.g., pollutant uptake (Berglund et al. 2019; Nugroho and Frank 2011), molecular and behavioral biomarkers (Bielen et al. 2016; Falfushynska et al. 2013; Hartmann et al. 2016; Oliviera et al. 2015), and mortality (Kováts et al. 2010; Oliviera et al. 2015). The reproductive cycle of $A$. anatina includes a gravid stage during autumn/winter (Aldridge 1999; Hinzmann et al. 2013), potentially increasing variability in transcriptional and biochemical biomarkers (Ekelund Ugge et al. 2020).
Our objectives were to (1) evaluate selected responses as biomarkers of sublethal exposure to chemically complex, anthropogenic pollution and (2) assess A. anatina as a bioindicator species. An industrial wastewater effluent, i.e., a complex mixture, was used to represent an arbitrary anthropogenic stressor. While constituting a mixture of organic and inorganic substances, the main focus was, for practical reasons, limited to evaluation of metals. The selected biomarkers were assessed in A. anatina after acute $(96 \mathrm{~h})$ laboratory exposure to either a single effluent concentration or a control treatment of standardized freshwater. We hypothesized that (1) biomarker signals in digestive glands and gills would differ between effluent exposed and non-exposed mussels and that (2) gravid mussels would show different baseline signals (fixed effects) and/or response magnitudes (treatment interactions) compared to non-gravid.

\section{Material and methods}

\section{Mussel collection and maintenance}

Adult mussels (length $92 \pm 17 \mathrm{~mm}$ ) were collected on September 19, 2018, in Vinne å (Southern Sweden, 56 06 $45^{\prime \prime} \mathrm{N}, 13^{\circ} 54^{\prime} 35^{\prime \prime} \mathrm{E}$ ). The location is adjacent to human settlement and subject to, e.g., recreational fishing, but free from point sources of pollution. After being brought to the laboratory, the mussels were acclimatized to laboratory conditions for 26 days. During this period, a preliminary range-finding experiment was performed on a different subset of mussels (details presented in appendix A). Acclimatizing mussels were kept in two $40 \mathrm{~L}$ aquaria containing $30 \mathrm{~L}$ continuously aerated standardized freshwater (ISO 6341: 2012) with a nominal water hardness of $250 \mathrm{mg} / \mathrm{L} \mathrm{CaO}_{3}$. As bottom substrate, each aquarium contained an approximately $5 \mathrm{~cm}$ sand layer $(0.2$ $0.7 \mathrm{~mm}$ grain size). Standardized freshwater and bottom substrate were both prepared as previously reported (Ekelund Ugge et al. 2020). Three times weekly, 15-20 L medium was renewed, and main experiment mussels were randomly re-distributed between aquaria to avoid tank effects on acclimatization. Additions of Pseudokirchneriella subcapitata were made to feed the mussels, corresponding to approximately $3.2 \times 10^{6}$ cells $\times$ mussel $^{-1} \times$ day $^{-1}$. No food was added within $48 \mathrm{~h}$ prior to the start of the experiment. During acclimatization and experimental periods, water temperature was $21 \pm 1^{\circ} \mathrm{C}$, and the light cycle was $16 \mathrm{~h}$ light: $8 \mathrm{~h}$ dark.

\section{Experimental treatment}

Frozen samples of treated effluent water were obtained from an industrial wastewater treatment facility. The facility receives process and sanitary wastewater, as well as runoff, from an industrial area where mainly organic chemical products are 
manufactured. Compounds such as organic acids, phenols, and aldehydes may occur at high concentrations in incoming wastewater but are efficiently removed in the treatment process (personal communication). Phenol and aldehyde samples from the sampling period measured $<0.05 \mathrm{mg} / \mathrm{L}$ and $<0.5 \mathrm{mg} /$ $\mathrm{L}$, respectively, as reported by the industry. Other plausible organic contaminants from raw materials and manufactured products have previously been analyzed but not detected and are therefore not routinely monitored. The industry reported an effluent total organic carbon (TOC) content ranging between 31 and $36 \mathrm{mg} / \mathrm{L}$ for the period when water was sampled (median $33 \mathrm{mg} / \mathrm{L}$ ). Based on previous evaluation, this is assumed to largely consist of non-toxic microbial degradation products (personal communication). Organic pollutants were therefore not measured in this study, and instead, metal contamination was selected as the main focus and used as a proxy to represent the chemical complexity. Effluent metal concentrations are continuously monitored by the industry, and contamination is believed to result mainly from corrosion and erosion of, e.g., metal piping, galvanized steel, and stainless steel equipment, in the processing of organic compounds. A minor fraction is believed to result directly from manufacturing of metal containing products, and in addition, there might be metal contamination from raw materials and runoff from loading areas (personal communication).

Eight effluent samples, representing 8 consecutive days of effluents from the treatment facility, were thawed and mixed flow proportionally. During exposure, mussels were kept individually in glass containers $(\varnothing 12 \mathrm{~cm})$ of $1 \mathrm{~L}$ aerated medium (effluent or standardized freshwater), with $0.3 \mathrm{~L}$ sand added as bottom substrate. Light, temperature, and feeding conditions were the same as during acclimatization. Acute exposures of $96 \mathrm{~h}$ were performed as a trade-off between capturing immediate responses and allowing for potential time-dependent uptake of pollutants. After $96 \pm 0.5 \mathrm{~h}$, mussels were dissected. Gravid mussels were distinguished visually by the presence of immature glochidia in the gills (Figure A.1, appendix A). Gill and digestive gland tissues were dissected, and subsamples were immediately snap frozen in liquid nitrogen and subsequently stored at $-80^{\circ} \mathrm{C}$ for biochemical assays and chemical analysis or submerged in RNA-Later (Invitrogen, USA) and stored at $-20^{\circ} \mathrm{C}$ for gene expression analyses.

A preliminary range-finding experiment was performed to select an effluent concentration for the main exposure experiment (details presented in appendix A). A dilution to $60 \%$ of the initial concentration was selected, as this was the highest test concentration that did not appear to impair mussel filtration (roughly estimated by daily visual inspection of valve opening). In addition, this exposure, although overlapping with control treatment variation and not being replicated, showed implication of AChE inhibition (Figure A.2, appendix A).
In the main experiment, mussels were exposed to $60 \%$ industrial effluent water $(n=16)$ or a control treatment of standardized freshwater $(n=16)$. Glass containers with exposure media were prepared and kept under aeration approximately $24 \mathrm{~h}$ prior to experimental start. Before the addition of mussels, each container was sampled for chemical analysis of exposure media. $\mathrm{pH}$ and oxygen were monitored at $0 \mathrm{~h}, 48$ $\mathrm{h}$, and $96 \mathrm{~h}$. Initial $\mathrm{pH}$ was $7.8( \pm 0.04)$ and $8.2( \pm 0.03)$ in control and effluent treatments respectively, steadily decreasing to $7.1( \pm 0.3)$ and $7.7( \pm 0.2)$ after $96 \mathrm{~h}$. Oxygen saturation was consistently $\geq 90 \%$ (7.9-9.1 mg $\left.\mathrm{O}_{2} / \mathrm{L}\right)$ in all containers, except for one effluent container in which saturation was $80 \%$ (7.1 $\mathrm{mg} \mathrm{O}_{2} / \mathrm{L}$ ) at $48 \mathrm{~h}$. After the experiment was ended, distribution of gravid and non-gravid mussels was determined to be 3:13 and 5:11 in the control and effluent treatment, respectively.

\section{Chemical analysis}

A number of elements were analyzed in exposure media sampled (non-filtered) at the experimental start (Table 1) and in water samples from Vinne å (Table A.1, appendix A). Samples were kept frozen $\left(-20^{\circ} \mathrm{C}\right)$ prior to analysis, and one control treatment sample was lost during freezing. Upon arrival to the chemical analysis laboratory, the water samples were acidified by addition of nitric acid $(1 \% \mathrm{v} / \mathrm{v})$, then analyzed by inductively coupled plasma sector field mass spectrometry (ICP-SFMS) (Element, Thermo Scientific, Germany), inductively coupled plasma atomic emission spectrometry (ICP-AES) (Agilent ICP-OES 725, Agilent, USA), and atomic fluorescence spectrometry (AFS) (PSA Millennium Merlin, P S Analytical, UK) according to standards from the International Organization for Standardization and the US Environmental Protection Agency (ISO 17852:2006, 11885:2007, 17294-2:2016. U.S. EPA 1994a, 1994b). Metal content was also determined in snap frozen tissue samples remaining after biochemical assays. Tissues were subject to nitric acid/hydrogen peroxide digestion, and metals were analyzed by ICP-SFMS (Element 2, Thermo Scientific, Germany) (ISO 17294-2: 2016; U.S. EPA 1994b) (Table 1).

\section{Estimation of chemical stress}

Toxic units (TUs) were calculated for sublethal organism effects (behavioral/ growth/ physiological/cellular/biochemical endpoints) and mortality, respectively ( $\mathrm{TU} \mathrm{EC}_{50}$ and $\mathrm{TU}$ $\mathrm{LC}_{50}$ ), to quantitatively estimate the chemical stress imposed by effluent exposure. TUs were determined for elements measured in water, a priori excluding the non-metals $\mathrm{P}$ and $\mathrm{Si}$ as well as macrominerals $\mathrm{Ca}, \mathrm{K}, \mathrm{Na}$, and $\mathrm{Mg}$. Elements for which toxicity data was not found were simply reported as "not applicable" (NA) (Table A.2, appendix A). Mollusk 96-h 50\% 


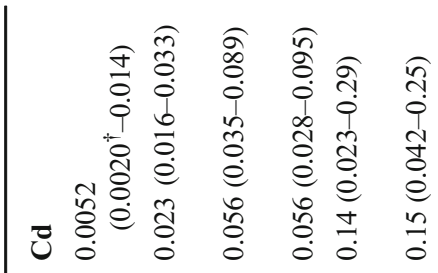

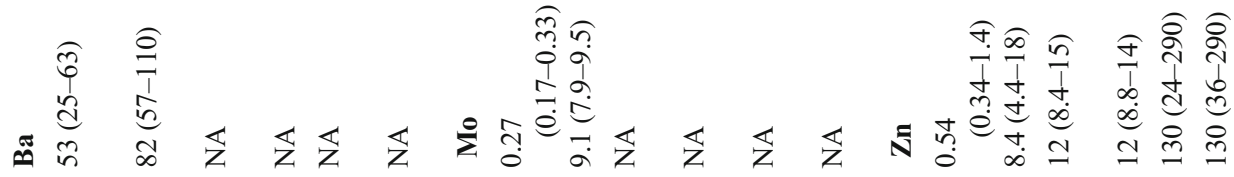

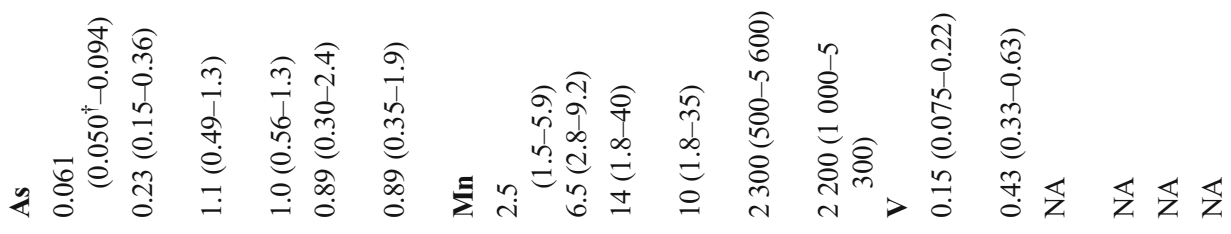

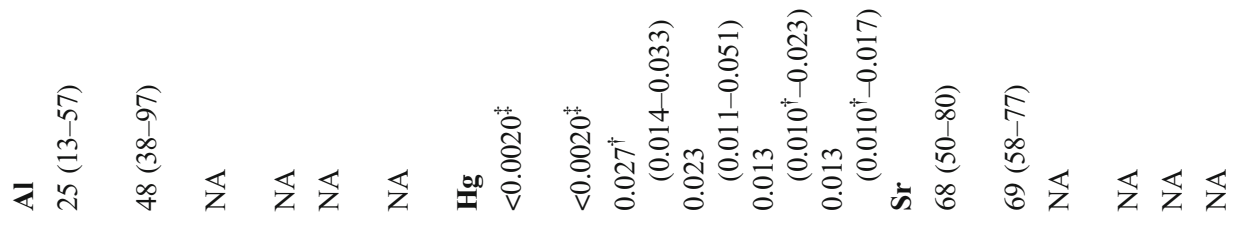

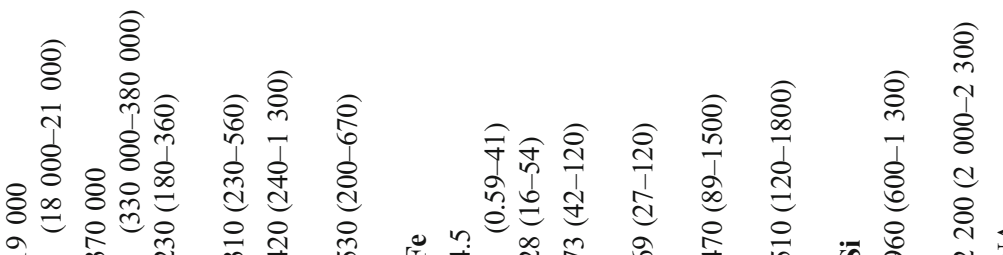

的乲

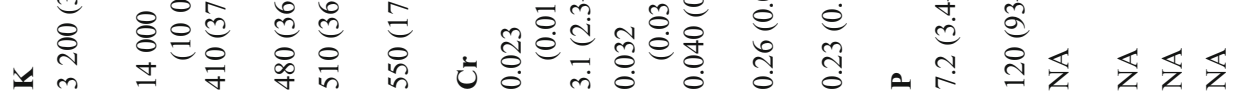


effect concentrations $\left(\mathrm{EC}_{50}\right)$ and $96-\mathrm{h} 50 \%$ lethal concentrations $\left(\mathrm{LC}_{50}\right)$ from laboratory experiments were retrieved from the US EPA ECOTOX database (https://cfpub.epa.gov/ ecotox/) on September 7-8, 2020 (details presented in appendices B and C, deposited at https://data.mendeley.com/ datasets/jc469bc5mv/1). Toxic units ( $\mathrm{TU} \mathrm{EC}_{50}$ and $\mathrm{TU} \mathrm{LC}_{50}$ ) were calculated for each metal as $\mathrm{TU} \mathrm{XC}_{50}=$ Measured conc. /Mollusk $96 \mathrm{~h} \mathrm{XC}_{50}$, with measured concentration and effect concentration represented by the respective median. TUs for all metals were added, as $T U_{M} X C_{50}=\sum T U X C_{50}$, to represent additive mixture toxicity $\left(\mathrm{TU}_{\mathrm{M}} \mathrm{EC}_{50}\right.$ and $\mathrm{TU}_{\mathrm{M}}$ $\mathrm{LC}_{50}$ ) for each treatment (Table A.2, appendix A).

As an additional estimate of relative contributions to stress, measured metal concentrations were, when applicable, converted to fraction of the respective environmental quality standards (EQSs) for inland surface waters, as Fraction of EQS = Measured conc. /EQS. Measured concentrations were represented by the median of measured total concentration, and EQSs by the respective annual mean EQS from European and Swedish legislation (European Parliament and Council 2013; Havs- och vattenmyndigheten 2019) (Table A.2, appen$\operatorname{dix}$ A).

\section{Biomarker assays}

The biomarker selection consisted of eight molecular biomarkers. The enzymatic assays for AChE and GST activities were based on the rates for hydrolysis of acetylthiocholine (Bocquené and Galgani 1998) and glutathione conjugation to 1-chloro-2,4-dinitrobenzene (Habig et al. 1974), respectively. Samples were prepared in phosphate buffers, and spectrophotometric analyses (using a SpectraMax 190 plate reader (Molecular Devices, USA)) were performed, all according to previous description (Ekelund Ugge et al. 2020). All enzyme activities were normalized, first by sample protein concentration (Bradford 1976) and second to the mean activity of control samples of the respective tissue.

For transcriptional markers (cat, gst, hsp 70, hsp $90, m t$, and $s o d$ ), relative transcript levels were measured by reverse transcription quantitative polymerase chain reaction (RT-qPCR). RNA was extracted using the Norgen's Total RNA Purification Kit (Norgen, Canada), including $40 \mu \mathrm{M}$ of DLdithiothreitol (DTT, Promega, USA) in the lysis buffer. Tissues were homogenized using a TissueLyser II (Qiagen, Germany) and 5-mm stainless steel beads (Qiagen, Germany). RNA amounts and A260/A280 ratios (showing 1.9-2.1) were measured using a NanoDrop 2000 spectrophotometer (Thermo Scientific, USA). Before cDNA synthesis, the RNA was DNAse treated using the Heat\&Run gDNA removal kit according to instructions (ArcticZymes, Norway), and the RNA integrity was assessed in randomly selected subset of samples using a Fragment Analyzer (Advanced Analytical, Austria). Since our interest was relative rather than absolute gene expression, and only short sequences were targeted ( $<200$ bp, Ekelund Ugge et al. 2020, appendix), reverse transcription was performed despite apparent RNA degradation (RNA quality numbers (RQN) of 1.82.3 and $2.8-4.5$ in the gills and digestive glands, respectively). cDNA was synthesized by reverse transcription of $200 \mathrm{ng}$ and 100 ng RNA for digestive gland and gills, respectively, using the TATAA GrandScript cDNA synthesis kit (TATAA Biocenter AB, Sweden). The qPCR assays were performed as previously described (primer sequences are presented in Table A.3, appendix A, and assay details are found in Ekelund Ugge et al. 2020). Gene expression was determined by the $2^{-\Delta \Delta \mathrm{Ct}}$ method (Livak and Schmittgen 2001), where expressions were normalized by the mean of control samples of the gill and digestive gland tissue, respectively, and then internally for each individual sample by the mean of two reference genes, $\beta$-actin and $28 S$ rRNA.

\section{Statistics}

Statistical analyses were run and figures were generated in $\mathrm{R}$ version 4.0.2 (R Core Team 2020). For the principal component analysis (PCA), water and tissue concentrations of measured metals were normalized as percentage of the respective mean from control samples and $\log _{10}$-transformed. For various chemical parameters, there were samples showing concentrations below the levels of reporting (LOR). Unless that was true for the majority ( $\geq 50 \%$ ) of samples, concentrations $<$ LOR were assumed to equal the respective LOR. If, however, a majority of samples displayed concentrations $<$ LOR, as for $\mathrm{Hg}$ in water and $\mathrm{Pb}$ in digestive glands, the parameter was removed completely from the respective PCA. For elements measured in both tissue and water samples, correlations (Pearson) were determined for measured concentrations ( $\log _{10}$-transformed), excluding datapoints for which either concentration (tissue or water) was $<$ LOR. Biomarker responses ( $\log _{2}$-transformed) were analyzed by linear models and separated by tissue. Treatment, sex, and the treatment/ sex interaction were used as fixed factors in the full models. Model selection for linear models was based on lowest AIC scores after sequential ANOVA analysis, where least significant $(p>0.05)$ effect factors were removed one at a time. Residual normality for biomarker responses was assessed by Shapiro-Wilk normality tests and Q-Q plots. Significant differences $(\alpha=0.05)$ in the final models were identified with a Tukey HSD post hoc test, using the "emmeans" package (Lenth 2020). Treatment effects on overall variation were assessed by a paired $t$-test, in which the coefficient of variation (CV) of each biomarker/tissue pair was compared between control and exposed mussels. CV was calculated by dividing each biomarker/tissue standard deviation by corresponding mean response (non-log-transformed). Finally, the "ggplot2" package (Wickham 2016) was used to produce all figures. 


\section{Results}

With regards to chemical composition, digestive gland control and effluent samples were slightly separated along principal component 2 of the PCA (Figure 1A), while there was no apparent difference in gills (Figure 1B). The control and effluent exposure media were however highly separated along principal component 1 (Figure 1C). Most concentrations were higher in the effluent medium than in the control medium, many by an order of magnitude (e.g., $\mathrm{Na}, \mathrm{Co}, \mathrm{Cu}, \mathrm{Fe}, \mathrm{Mo}$, $\mathrm{P}$, and $\mathrm{Zn}$ ) or more (e.g., $\mathrm{Cr}$ and $\mathrm{Ni}$ ) (Table 1). The only elements at higher concentration in the control medium were $\mathrm{Ca}$ and $\mathrm{Mg}$, with roughly twice as high concentrations as in the effluent exposure. In contrast, tissue levels were overall similar between treatments (Table 1). The most notable difference was an approximately 2 -fold higher digestive gland concentration of $\mathrm{Ni}$ in exposed mussels compared to control, positively correlated to exposure concentration (Table 1, Figure A.3, Table A.4, appendix A). In addition, digestive gland $\mathrm{Na}$ levels were also positively correlated to exposure concentration, while no correlation was detected between tissue and water concentrations of $\mathrm{As}, \mathrm{Ca}, \mathrm{Cd}, \mathrm{Co}, \mathrm{Cr}, \mathrm{Cu}, \mathrm{Fe}, \mathrm{K}$, $\mathrm{Mn}, \mathrm{Pb}$, and $\mathrm{Zn}$ (Figure A.3, Table A.4, appendix A).

The effluent and control $\mathrm{TU}_{\mathrm{M}} \mathrm{EC}_{50}$ were 0.15 and 0.020 , respectively (Table A.2, appendix A). This corresponds to approximately $1 / 7$ and $1 / 50$ of estimated median effect concentration for sublethal organism effects to occur. With regards to mortality, the effluent $\mathrm{TU}_{\mathrm{M}} \mathrm{LC}_{50}$ was $0.039(1 / 26$ of the estimated median lethal metal exposure), while the control $\mathrm{TU}_{\mathrm{M}} \mathrm{LC}_{50}$ was 0.0028 (1/360 of the median lethal exposure) (Table A.2, appendix A). Based on TU estimations, $\mathrm{Cu}$ contributed the most to metal toxicity, followed by $\mathrm{Ni}, \mathrm{Zn}$, and $\mathrm{Al}(\mathrm{Al}>\mathrm{Zn}$ for sublethal organism effects, $\mathrm{Zn}>\mathrm{Al}$ for mortality). Finally, total concentrations of $\mathrm{Cu}, \mathrm{Ni}$, and $\mathrm{Zn}$ in the effluent exposure exceeded their respective EQS for bioavailable concentration in inland surface waters, by factors of 15 , 4.1, and 1.5, respectively, while $\mathrm{Cu}$ in the control exceeded the EQS by a factor of 1.4 (Table A.2, appendix A).

Only two of the eight biomarkers, AChE and hsp 90 , showed a significant treatment effect and interaction,
Figure 1 Principal component analyses of metal content (as well as $\mathbf{P}$ and $\mathrm{Si}$ content in water) in $\mathbf{A}$ digestive glands and $\mathbf{B}$ gills of Anodonta anatina after 96-h exposure to industrial wastewater effluent and $\mathbf{C}$ initial concentrations in water. Arrows show relative weights of each measured parameter and are scaled to the length of the plot axes
A

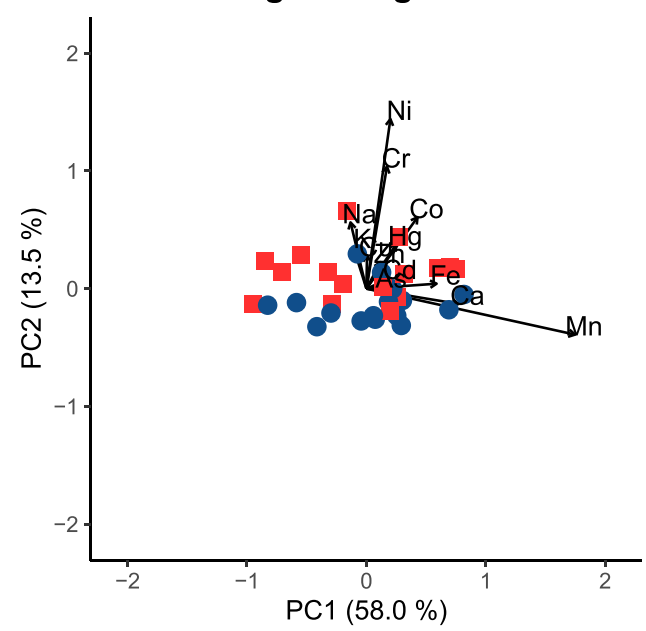

C

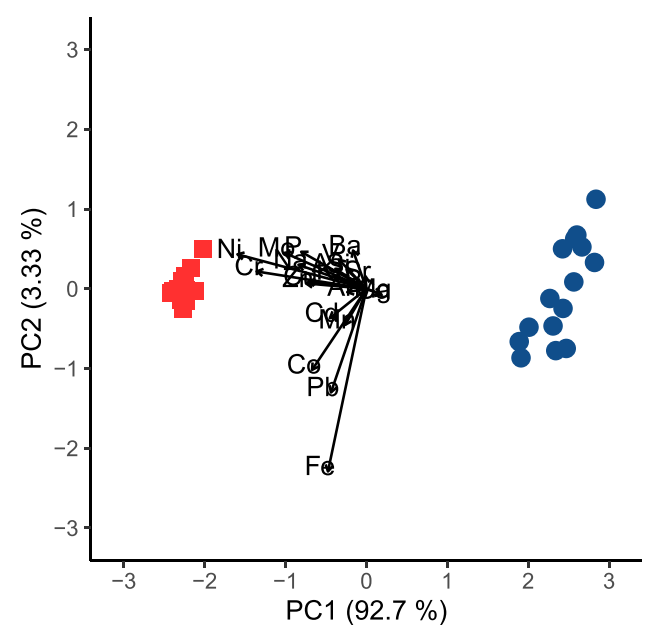

B Gills

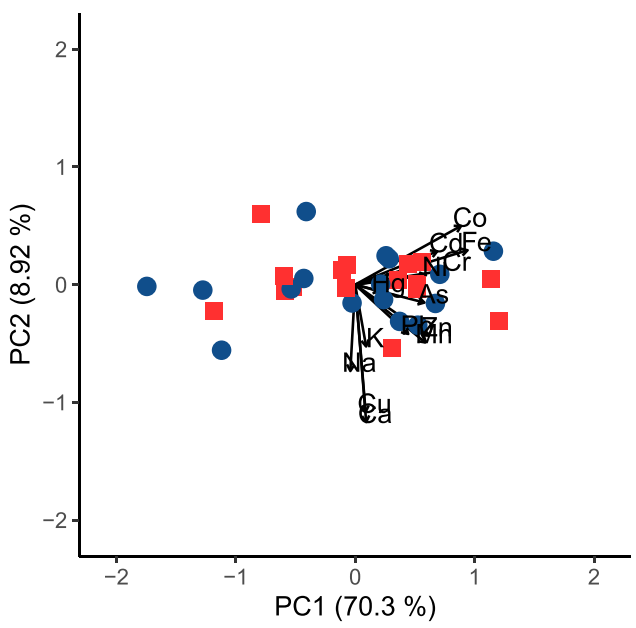

Treatment

- Control

Exposed 
respectively, and only in gills. Other biomarker responses to the effluent exposure were within $\pm 28 \%$ of the respective control ( $\log _{2}$ fold changes ranging from -0.19 to 0.36 ), across both gills and digestive glands (Table 2, Figures 2 and 3). AChE activity in exposed mussels was $40 \%$ higher than control $\left(\log _{2}\right.$ fold change $\left.=0.48\right)($ Table 2, Figure 2). For $h s p 90$, a treatment/sex interaction revealed a higher expression in both exposed females $\left(100 \%\right.$ higher, $\log _{2}$ fold change $\left.=1.0\right)$ and males $\left(79 \%\right.$ higher, $\log _{2}$ fold change $\left.=0.84\right)$ compared to control females (Table 2, Figure 2).

Two gills and one digestive gland biomarker showed sex differences, independent of treatment. AChE activity and hsp 70 expression were $61 \%$ higher and $36 \%$ lower, respectively, in male gills compared to females ( $\log _{2}$ fold changes $=$ 0.69 and -0.63 , respectively, Table 2, Figure 2). In digestive glands, males demonstrated a $37 \%$ higher baseline AChE activity than females $\left(\log _{2}\right.$ fold change $=0.46$, Table 2 , Figure 3).

Biomarker CVs ranged from 13 to $85 \%$ (Figure A.4, appendix A). Assessed pairwise across biomarkers and tissues; variation increased with effluent exposure in eleven out of 16 biomarker/tissue pairs, and decreased in five (Figure A.4, appendix A). The median CV increased from 32 in control treatments to $38 \%$ in the effluent group ( $p=0.017$, Figure A.4, appendix A).

\section{Discussion}

\section{Exposure and chemical stress}

The selected industry mainly produces organic chemical products (personal communication). Consistently, monitoring data from the industry showed TOC levels around $30 \mathrm{mg} / \mathrm{L}$ in the undiluted effluent, and we assumed elevated TOC for effluent exposures relative the control. By comparison, our daily feeding of the mussels would have added a negligible amount of up to approximately $100 \mu \mathrm{g}$ organic carbon $\mathrm{L}^{-1}$ day $^{-1}$ in each exposure tank, assuming an algal carbon content in the range of 5-30 pg/cell (e.g., Pérez-Morales et al. 2015). In routine monitoring performed by the industry, phenol and aldehyde levels in the effluent were typically below detection limits, and when analyzed, other plausible organic pollutants have not been detected. Therefore, without dismissing potential impact from or interactions with organic and other inorganic substances, the focus of this study was, however, narrowed down to metal toxicity, as a proxy of chemical stress from mixture toxicity.

The effluent metal content was in general, when adjusted for dilution, within the orders of magnitude previously reported by the industry (personal communication). The exceptions were $\mathrm{Ca}$ and $\mathrm{Mg}$, both occurring at approximately twice as high concentration in the control as in the exposure medium.
As essential components in the standardized freshwater, they are assumed non-toxic at current concentrations. Remaining metals occurred at higher concentration compared to the control treatment, suggesting that the effluent exposure might, by comparison, be viewed as a complex chemical stressor, even without considering the potential contribution from organic or other inorganic compounds.

Effluent $\mathrm{TU}_{\mathrm{M}} \mathrm{EC}_{50}$ and $\mathrm{TU}_{\mathrm{M}} \mathrm{LC}_{50}$ were both an order of magnitude higher than the control, further implying a higher level of chemical stress. Three of the metals contributing most to toxicity, $\mathrm{Cu}, \mathrm{Ni}$, and $\mathrm{Zn}$, showed levels at least an order of magnitude higher as compared to the control. Total concentrations of these metals exceeded their respective EQS for inland surface waters, although environmental impact assessment is to be based specifically on the bioavailable fraction. For instance, metal bioavailability can decrease with, e.g., water hardness and dissolved organic carbon (Bourgeault et al. 2010; Shoults-Wilson et al. 2010; Wang et al. 2009), implying bioavailability below $100 \%$ of the total concentration under current settings. On the other hand, effluent concentrations of $\mathrm{Cu}, \mathrm{Ni}$, and $\mathrm{Zn}$, but also e.g. $\mathrm{Cr}$, were all within ranges that separately may trigger various molecular responses in bivalves upon acute (72-96 h) exposures (e.g., Ciacci et al. 2012; Franzellitti et al. 2020; Li et al. 2018; Potet et al. 2016). We therefore argue that the current effluent exposure represents a sublethal acute stressor to which molecular responses, albeit not whole-organism effects, would be expected.

Metal uptake in bivalve soft tissues may be observable within hours (e.g., Cai and Wang 2019; Lee and Lee 2005), suggesting that 96-h exposure would be sufficient for uptake to occur. Yet, apart from $\mathrm{Ni}$ and $\mathrm{Na}$ in digestive glands, we could detect no correlation between external exposure and tissue concentration. The body burden depends on uptake from water, dietary uptake, and elimination rates, all of which are variable (Luoma and Rainbow 2005), and even with sufficient time, uptake might be limited by bioavailability. On the other hand, dietary sources might contribute substantially to total metal uptake (Lee et al. 2015; Luoma and Rainbow 2005). Filter feeding would thus be a potential exposure route of metals associated with algal cells or present in particulate forms (Hull et al. 2013; Lee et al. 2015). Considering the static exposure and moderate concentrations of each separate metal, elimination rates after $96 \mathrm{~h}$ might have been high enough to balance potential uptake (King et al. 2005; Nugroho and Frank 2011). Another potential explanation is that the effluent might trigger avoidance behavior to reduce the actual exposure (Hartmann et al. 2016). Avoidance was however not tested and not specifically noted upon visual inspection (e.g., prolonged valve closure), except for the $100 \%$ effluent exposure in the preliminary experiment. Regardless, the overall implication, based on measured water and tissue concentrations, is that metal uptake was in most cases balanced or exceeded by excretion. 


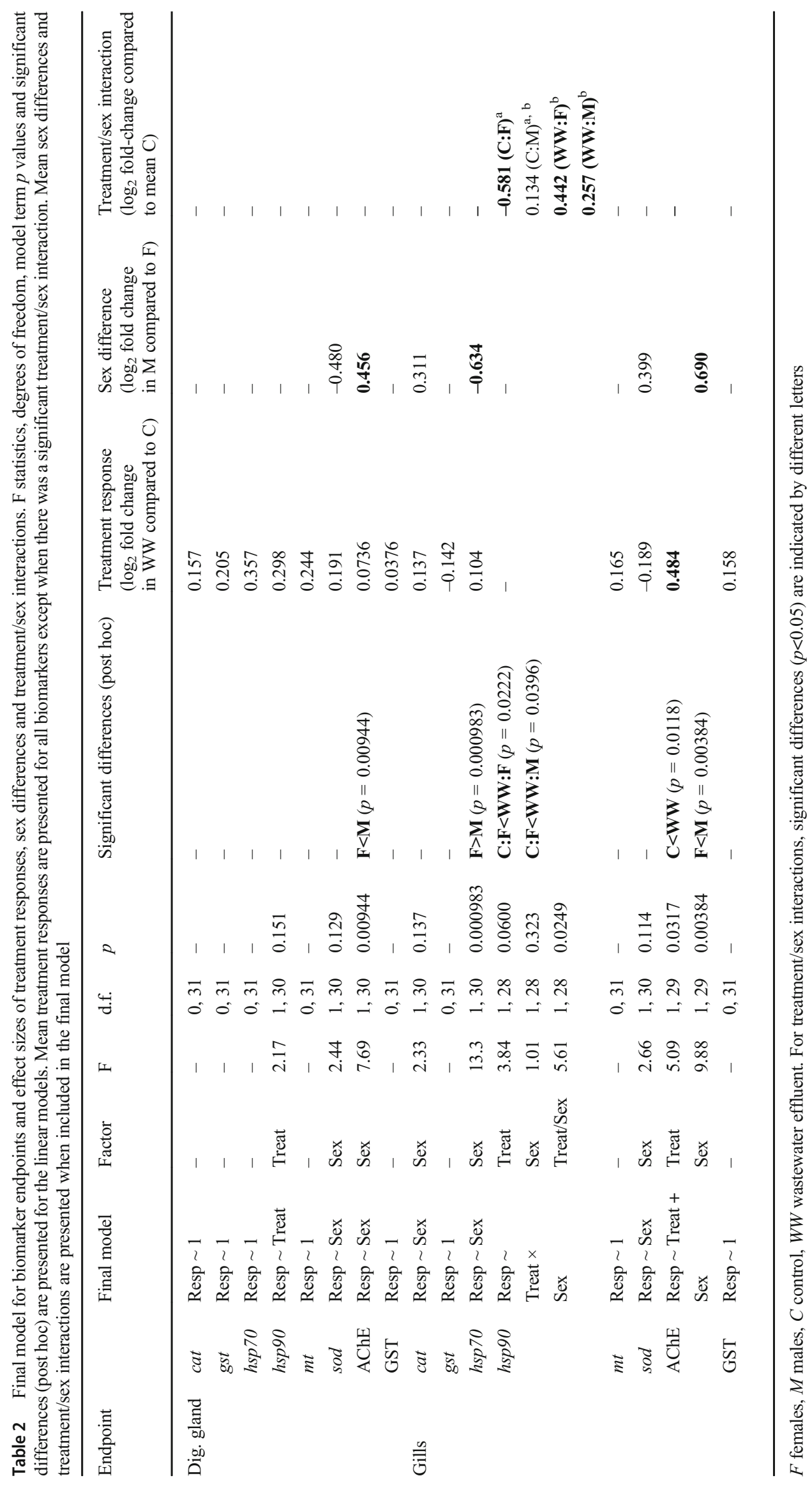



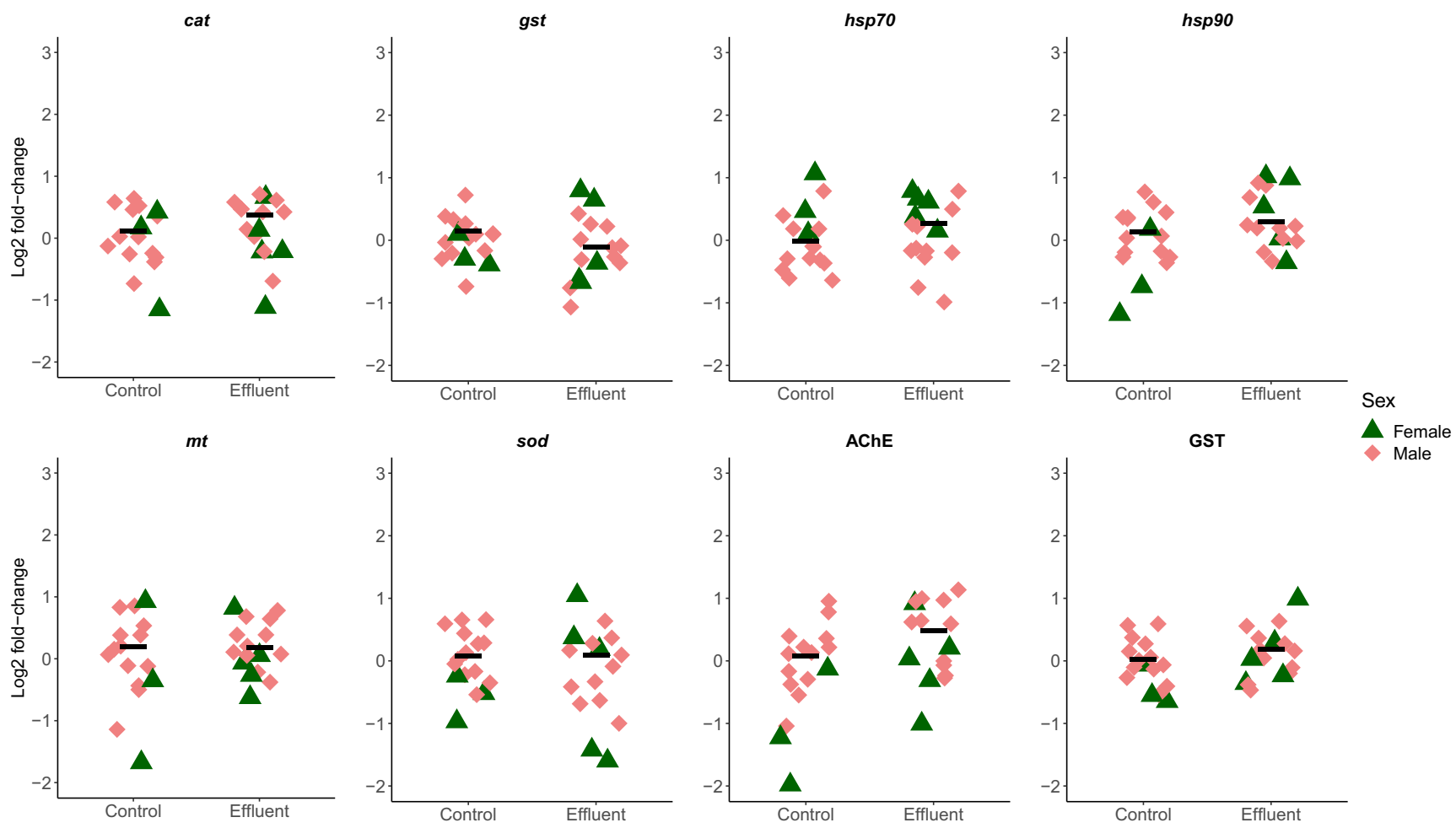

Figure 2 Biomarker responses $\left(\log _{2}\right.$ fold change relative control) in gills of Anodonta anatina exposed to a control treatment $(\mathrm{n}=16)$ or an industrial wastewater effluent $(n=16)$ for $96 \mathrm{~h}$. Bars correspond to median responses

\section{Treatment effects}

Stress proteins (here $h s p 70, h s p 90$, and $m t$ ) and markers of redox homeostasis (here cat, gst, GST, and sod) have been suggested as two key groups of biomarkers for general metal toxicity (Le Saux et al. 2020). Even low metal concentrations have been demonstrated to increase bivalve expression and activity of cat, gst, GST, hsp70, $\mathrm{mt}$, and sod by $\geq 50 \%$ (e.g., Ciacci et al. 2012; Franzellitti et al. 2020; Li et al. 2018; Perić and Burić 2019). In contrast, effect sizes from the effluent exposure were overall small. The mussel gill is the first organ in contact with waterborne pollutants, which may explain the responses in AChE and $h s p 90$. However, apart from $\mathrm{AChE}$ and $h s p 90$, all gill biomarker signals in the effluent exposure were within $\pm 12 \%$ of the control. Hence, potential responses were not distinguishable from baseline noise. In digestive glands, all biomarkers responded to the effluent by $\leq 28 \%$ increases, consistently non-significant despite elevated tissue levels of, e.g., Ni. One possible explanation could be a certain level of general metal tolerance, as the experimental mussels had previously been exposed to higher concentrations of, e.g., $\mathrm{Fe}, \mathrm{Mn}$, and $\mathrm{Al}$ (Table A.1, appendix A). Adaptation to metal exposure might for instance cause inter-population differences in transcriptional response patterns (Milan et al. 2016). This would affect the predictability of, e.g., biomarker effect sizes, potentially reducing the general sensitivity to relevant changes in the environment.
Furthermore, it is possible that larger effect sizes would have been observed in immediate or long-term responses, but simply not captured by the 96-h static exposure. In order for a biomarker to be robust in, e.g., environmental monitoring, responses also require a certain degree of stability over time. Thus, results suggest that selected biomarkers, with potential exceptions of gill AChE and hsp90, were separately not robust and/or not sensitive enough to detect the effluent exposure in particular and perhaps not low to moderate stress in general.

AChE activity is quite commonly inhibited by chemical stressors (Bocquené and Galgani 1998). For instance, AChE inhibition has been demonstrated in Anodonta cygnea, a close relative to A. anatina, after acute exposure to low levels of a complex metal mixture (Butrimavičienè et al. 2019). While performed without replication of the effluent treatments, implication of AChE inhibition was also observed in our preliminary experiment, however, overlapping with the response range in the control group. In contrast, the main experiment demonstrated a clear $40 \%$ increase in AChE gill activity in the effluent exposure. These seemingly contradictive results likely reflect high $\mathrm{AChE}$ variability and insufficient replication in the preliminary experiment. In fact, increased activity of $\mathrm{AChE}$ and other cholinesterases has been previously observed in other taxa after acute metal exposures (Brahma and Gupta 2020; Dahms-Verster et al. 2020; Oliva et al. 2019). Taken together, this suggests that $\mathrm{AChE}$ in A. anatina is quite 

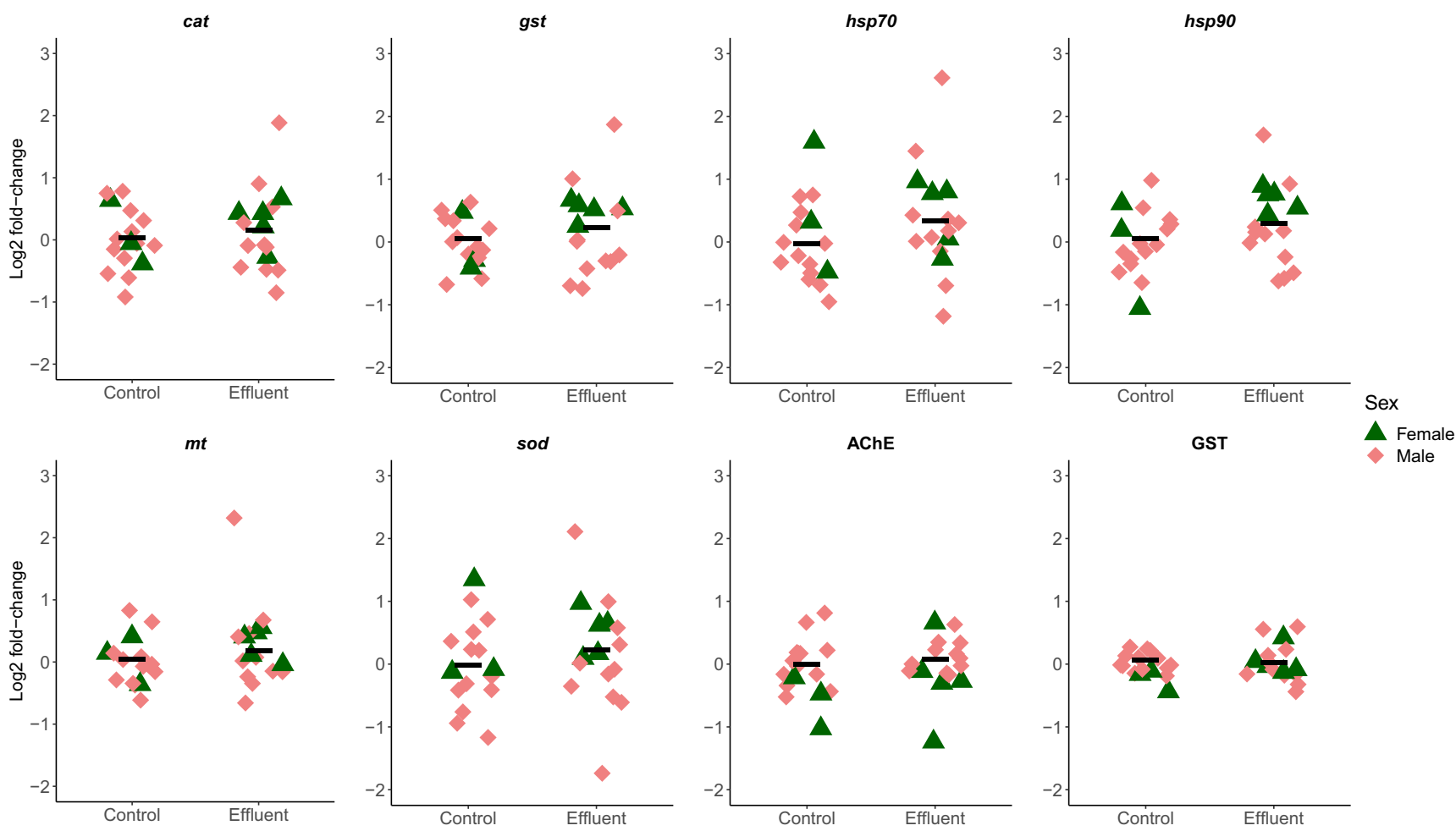

Figure 3 Biomarker responses ( $\log _{2}$ fold change relative control) in digestive glands of Anodonta anatina exposed to a control treatment $(\mathrm{n}=16)$ or an industrial wastewater effluent $(n=16)$ for $96 \mathrm{~h}$. Bars correspond to median responses

variable, and that this enzyme might be less robust as a biomarker than what is often assumed.

Expression of $h s p 90$ demonstrated a treatment/sex interaction in gills. In this general stress marker, effluent exposure induced a $79-100 \%$ higher expression in both males and females but only compared to control females. This suggests that at least in gravid females, current stress levels were enough to induce a clearly detectable biomarker response. Still, it must be noted that both treatment groups consisted of 70-80\% males, which for $h s p 90$ would obscure this effect if not including sex in the model. Therefore, without consideration of sex interactions, only a single biomarker (AChE in gills) showed a distinguishable treatment response under current exposure.

\section{Sex effects and response variability}

Consistent with previous findings in A. anatina (Ekelund Ugge et al. 2020), we found higher $h s p 70$ expression in gills and lower $\mathrm{AChE}$ activity in digestive glands of gravid females, compared to males. In addition, the current study detected a sex effect in gill $\mathrm{AChE}$ activity as well as the $h s p 90$ treatment/sex interaction (discussed under the "Treatment effects" section), while there were no differences in, e.g., cat, $m t$, or GST as described previously (Ekelund Ugge et al. 2020). The different observations could result from random variation or differences between experiments (e.g., experiments carried out at different temperatures, mussels potentially collected or exposed at different stages of gravidness). Overall, the results therefore highlight biomarker variability, suggesting sex, and in particular gravidness, as potential confounding factors.

Responses to chemical stress may to a certain extent be buffered by various biological and ecological processes, and responses on one level often do not translate proportionally to adverse effects at higher organizational levels (e.g., Forbes and Calow 2002; Geist et al. 2007). Conversely, even when the mean response of an ecotoxicological endpoint remains unaffected by stress, underlying variation can potentially increase, and thus, response variability has in itself been suggested as a relevant toxicological endpoint (Nikinmaa and Anttila 2019). In addition to variability introduced by sex differences, we demonstrated an increase in variation for a majority of markers in A. anatina from the effluent exposure. In, e.g., risk assessment and environmental monitoring, biological responses to chemical stress should preferably be approached both by using multiple biomarkers (ideally in multiple tissues) and by incorporating variability measures in such biomarker panels.

\section{Conclusions}

The small effect sizes suggest an inability of the chosen biomarkers to reliably indicate exposure to anthropogenic effluents in A. anatina. Only two biomarkers, one biochemical and one transcriptional, responded to exposure. Furthermore, 
despite increased tissue concentration of $\mathrm{Ni}$ in digestive glands, treatment responses were only observed in gills. This is further complicated by the confounding factor gravidness, which mainly appears to affect gill responses. An overall increase in variation across markers after the effluent exposure suggests that multi-biomarker approaches may potentially increase robustness for detection of chemical stress, despite (and potentially due to) high inherent variability of the separate markers. In future research, we propose continued assessment of multi-biomarker approaches as well as inter- and intrapopulation variability, both in terms of confounding effects and marker variation as a potential endpoint in itself.

Supplementary Information The online version contains supplementary material available at https://doi.org/10.1007/s11356-021-15633-4.

Acknowledgements We thank the anonymous chemical company for providing effluent water and Anders Sjölin (NIRAS Sweden AB, Malmö, Sweden) for coordination of project logistics. We also thank Anders Walstad and Susanne Fritz of ALS Scandinavia Toxicon AB for assistance with mussel maintenance and Robert Sjöback, Alexandra Bergman, and Andrei Herdean of TATAA Biocenter AB for collaboration and assistance with qPCR assays. Finally, we thank the two anonymous reviewers for providing helpful feedback for improving the manuscript.

Exposure treatments and biochemical assays were performed in the ALS Scandinavia Toxicon AB laboratory facilities. RNA extraction was performed in the Aquatic Ecology DNA lab and the Molecular Ecology and Evolution Lab (MEEL), Department of Biology, Lund University (Lund, Sweden). The cDNA synthesis, RNA fragment analysis, and qPCR assays were performed at TATAA Biocenter AB. Chemical analyses were performed by ALS Scandinavia.

Author contribution Gustaf Ekelund Ugge conceptualized and designed the study with support and supervision from Olof Berglund and Annie Jonsson. Experiments and analyses were carried out by Gustaf Ekelund Ugge, who also wrote the original draft. All authors contributed to and approved the final version of the manuscript.

Funding Open access funding provided by Lund University. This work was supported by the Swedish Knowledge Foundation and Jörgen Lindström's Foundation, and co-funded by ALS Scandinavia Toxicon AB (Landskrona, Sweden) and TATAA Biocenter AB (Gothenburg, Sweden) as part of the project WaterAssess. An anonymous chemical company provided the tested effluent water.

TATAA Biocenter $\mathrm{AB}$ was involved in designing and performing the transcriptional biomarker assays, and ALS Scandinavia (Luleå, Sweden; parent company of Toxicon AB) performed the chemical analyses of tissue and water samples. Staff from ALS Scandinavia Toxicon AB occasionally assisted in laboratory maintenance (feeding mussels and measuring water $\mathrm{pH} / \mathrm{O}_{2}$ ). Parts of the manuscript were discussed with a representative from the anonymous chemical company before submission to agree on technical descriptions of the industry and the effluent. Otherwise, no funding sources were involved in designing the experiments, collecting data, or writing the manuscript.

Availability of data and materials Experimental datasets, as well as literature datasets used for toxic unit (TU) calculations, can be found at https://data.mendeley.com/datasets/jc469bc5mv/1.

\section{Declarations}

Ethics approval and consent to participate The work was carried out in accordance with Swedish legislation and mussels were collected in agreement with the fishing holder of Vinne å.

Consent for publication The chemical company providing effluent water has consented to publication but has requested to remain anonymous. We ask readers to stay aware that our results represent a static laboratory exposure, and as such they should not be interpreted as representative of conditions in the actual recipient.

Competing interests Gustaf Ekelund Ugge is employed by ALS Scandinavia Toxicon $\mathrm{AB}$, but is on a leave of absence for pursuing a $\mathrm{PhD}$.

In order to ensure anonymity as well as technical correctness, a representative of the anonymous chemical company was allowed to read a draft of the manuscript prior to submission, to comment on descriptions of the industry, the wastewater treatment and routine measurements performed by the company.

Open Access This article is licensed under a Creative Commons Attribution 4.0 International License, which permits use, sharing, adaptation, distribution and reproduction in any medium or format, as long as you give appropriate credit to the original author(s) and the source, provide a link to the Creative Commons licence, and indicate if changes were made. The images or other third party material in this article are included in the article's Creative Commons licence, unless indicated otherwise in a credit line to the material. If material is not included in the article's Creative Commons licence and your intended use is not permitted by statutory regulation or exceeds the permitted use, you will need to obtain permission directly from the copyright holder. To view a copy of this licence, visit http://creativecommons.org/licenses/by/4.0/.

\section{References}

Aguirre-Martínez GV, Martín-Díaz ML (2020) A multibiomarker approach to assess toxic effects of wastewater treatment plant effluents and activated defence mechanisms in marine (Ruditapes philippinarum) and fresh water (Corbicula fluminea) bivalve species. Ecotoxicology 29:941-958

Aldridge DC (1999) The morphology, growth and reproduction of Unionidae (Bivalvia) in a Fenland waterway. J Molluscan Stud 65: $47-60$

Anliker S, Loos M, Comte R, Ruff M, Fenner K, Singer H (2020) Assessing emissions from pharmaceutical manufacturing based on temporal high-resolution mass spectrometry data. Environ Sci Technol 54:4110-4120

Aronzon CM, Peluso J, Coll CP (2020) Mixture toxicity of copper and nonylphenol on the embryo-larval development of Rhinella arenarum. Environ Sci Pollut Res 27:13985-13994

Bahamonde PA, Feswick A, Isaacs MA, Munkittrick KR, Martyniuk CJ (2016) Defining the role of omics in assessing ecosystem health: perspectives from the Canadian environmental monitoring program. Environ Toxicol Chem 35(1):20-35

Berglund E, Fogelberg V, Nilsson PA, Hollander J (2019) Microplastics in a freshwater mussel (Anodonta anatina) in Northern Europe. Sci Total Environ 697:134192

Bielen A, Bošnjak I, Sepčić K, Jaklič M, Cvitanić M, Lušić J, Lajtner J, Simčič T, Hudina S (2016) Differences in tolerance to anthropogenic stress between invasive and native bivalves. Sci Total Environ 543:449-459 
Bigot A, Minguez L, Giambérini L, Rodius F (2011) Early defense responses in the freshwater bivalve Corbicula fluminea exposed to copper and cadmium: transcriptional and histochemical studies. Environ Toxicol 26:623-632

Bocquené G, Galgani, F (1998) Biological effects of contaminants: cholinesterase inhibition by organophosphate and carbamate compounds. In: ICES Techniques in marine environmental sciences 22

Bourgeault A, Gourlay-Francé C, Tusseau-Vuillemin MH (2010) Modeling the effect of water chemistry on the bioaccumulation of waterborne cadmium in zebra mussels. Environ Toxicon Chem 29(10):2182-2189

Bradford MM (1976) A rapid and sensitive method for quantitation of microgram quantities of protein utilizing the principle of protein dye binding. Anal Biochem 72:248-254

Brahma N, Gupta A (2020) Acute toxicity of lead in fresh water bivalves Lamellidens jenkinsianus obesa and Parreysia (Parreysia) corrugata with evaluation of sublethal effects on acetylcholinesterase and catalase activity, lipid peroxidation, and behavior. Ecotox Environ Safe 189:109939

Butrimavičienè L, Stankevičiūtė M, Kalcienè V, Jokšas K, Baršienė J (2019) Genotoxic, cytotoxic, and neurotoxic responses in Anodonta cygnea after complex metal mixture treatment. Environ Sci Pollut Res 26:7627-7639

Cai C, Wang WX (2019) Inter-species difference of copper accumulation in three species of marine mussels: Implication for biomonitoring. Sci Total Environ 692:1029-1036

Cedergreen N (2014) Quantifying synergy: a systematic review of mixture toxicity studies within environmental toxicology. PLoS One 9(5):e96580

Chen C, Sun Y, Lan Q, Jiang F (2020) Impacts of industrial agglomeration on pollution and ecological efficiency - a spatial econometric analysis based on a big panel dataset of China's 259 cities. J Clean Prod 258:120721

Ciacci C, Barmo C, Gallo G, Maisano M, Cappello T, D’Agata A, Leonizio C, Mauceri A, Fasulo S, Canesi L (2012) Effects of sublethal, environmentally relevant concentrations of hexavalent chromium in the gills of Mytilus galloprovincialis. Aquat Toxicol 121122:109-118

Dahms-Verster S, Nel A, van Vuren JHJ, Greenfield R (2020) Biochemical responses revealed in an amphibian species after exposure to a forgotten contaminant: an integrated biomarker assessment. Environ Toxicol Pharmacol 73:103272

Ekelund Ugge GMO, Jonsson A, Olsson B, Sjöback R, Berglund O (2020) Transcriptional and biochemical biomarker responses in a freshwater mussel (Anodonta anatina) under environmentally relevant $\mathrm{Cu}$ exposure. Environ Sci Pollut Res 27:9999-10010

Ellis JB, Butler D (2015) Surface water sewer misconnections in England and Wales: Pollution sources and impacts. Sci Total Environ 526: 98-109

European parliament and council (2013) Directive 2013/39/EU of the European parliament and of the council of 12 August 2013 amending Directives 2000/60/EC and 2008/105/EC as regards priority substances in the field of water policy

Falfushynska HI, Gnatyshyna LL, Stoliar OB (2013) Effect of in situ exposure history on the molecular responses of freshwater bivalve Anodonta anatina (Unionidae) to trace metals. Ecotox Environ Safe 89:73-83

Farkas J, Polesel F, Kjos M, Almeida Carvalho P, Ciesielski T, FloresAlsina X, Foss Hanssen S, Booth AM (2020) Monitoring and modelling of influent patterns, phase distribution and removal of 20 elements in two primary wastewater treatment plants in Norway. Sci Total Environ 725:138420

Ferreira-Rodríguez N, Fernández I, Cancela ML, Pardo I (2018) Multibiomarker response shows how native and non-native freshwater bivalves differentially cope with heat-wave events. Aquat Conserv 28:934-943
Forbes V, Calow P (2002) Population growth rate as a basis for ecological risk assessment of toxic chemicals. Philos T R Soc B 357:12991306

Franzellitti S, Prada F, Viarengo A, Fabbri E (2020) Evaluating bivalve cytoprotective responses and their regulatory pathways in a climate change scenario. Sci Total Environ 720:137733

Geist J, Werner I, Eder KJ, Leutenegger CM (2007) Comparisons of tissue-specific transcription of stress response genes with whole animal endpoints of adverse effect in striped bass (Morone saxatilis) following treatment with copper and esfenvalerate. Aquat Toxicol 85:28-39

Gonzalez-Rey M, Mattos JJ, Piazza CE, Bainy ACD, Bebianno MJ (2014) Effects of active pharmaceutical ingredients mixtures in mussel Mytilus galloprovincialis. Aquat Toxicol 153:12-26

Habig WH, Pabst MJ, Jakoby B (1974) Glutathione-S-transferase. The first enzymatic step in mercapturic acid formation. J Biol Chem 249: 7130-7139

Hartmann JT, Beggel S, Auerswald K, Stoeckle BC, Geist J (2016) Establishing mussel behavior as a biomarker in ecotoxicology. Aquat Toxicol 170:279-288

Havs- och vattenmyndigheten (2019) HVMFS 2019:25. Havs- och vattenmyndighetens föreskrifter om klassificering och miljökvalitetsnormer avseende ytvatten

Herrero-Hernández E, Simón-Egea AB, Sánchez-Martín MJ, RodríguezCruz MS, Andrades MS (2020) Monitoring and environmental risk assessment of pesticide residues and some of their degradation products in natural waters of the Spanish vineyard region included in the Denomination of Origin Jumilla. Environ Pollut 264:114666

Hinzmann M, Lopes-Lima M, Teixeira A, Varandas S, Sousa R, Lopes A, Froufe E, Machado J (2013) Reproductive cycle and strategy of Anodonta anatina (L., 1758): Notes on hermaphroditism. J Exp Zool 9999:1-13

Hull MS, Vikesland PJ, Schultz IR (2013) Uptake and retention of metallic nanoparticles in the Mediterranean mussel (Mytilus galloprovincialis). Aquat Toxicol 140-141:89-97

ISO 17852 (2006) Water quality - Determination of mercury - method using atomic fluorescence spectrometry. International organization for standardization. First edition 2006-06

ISO 11885 (2007) Water quality - Determination of selected elements by inductively coupled plasma optical emission spectrometry (ICPOES). International organization for standardization. Second edition 2007-08

ISO 6341 (2012) Water quality - determination of the inhibition of the mobility of Daphnia magna Strauss (Cladocera, Crustacea) - acute toxicity test. International organization for standardization. Fourth edition 2012-10

ISO 17294-2 (2016) Water quality - Application of inductively coupled plasma mass spectrometry (ICP-MS) - Part 2: Determination of selected elements including uranium isotopes. International organization for standardization. Second edition 2016-07

King CK, Simpson SL, Smith SV, Stauber JL, Batley GE (2005) Shortterm accumulation of $\mathrm{Cd}$ and $\mathrm{Cu}$ from water, sediment and algae by the amphipod Melita plumulosa and the bivalve Tellina deltoidalis. Mar Ecol Prog Ser 287:177-188

Kováts N, Abdel-Hameid NA, Kovács K, Paulovits G (2010) Sensitivity of three unionid glochidia to elevated levels of copper, zinc and lead. Knowl Manag Aquat Econ 399:04

Le Saux A, David E, Betoulle S, Bultelle F, Rocher B, Barjhoux I, Cosio C (2020) New insights into cellular impacts of metals in aquatic animals. Environments 7(46)

Lee JS, Lee BG (2005) Effects of salinity, temperature and food type on the uptake and elimination rates of $\mathrm{Cd}, \mathrm{Cr}$, and $\mathrm{Zn}$ in the Asiatic clam Corbicula fluminea. Ocean Sci J 40(2):79-89

Lee JH, Birch GF, Cresswell T, Johansen MP, Adams MS, Simpson SL (2015) Dietary ingestion of fine sediments and microalgae represent the dominant route of exposure and metal accumulation for Sydney 
rock oyster (Saccostrea glomerata): a biokinetic model for zinc. Aquat Toxicol 167:46-54

Lehtonen KK, Turja R, Budzinski H, Devier MH (2016) An integrated chemical-biological study using caged mussels (Mytilus trossulus) along a pollution gradient in the Archipelago Sea (SW Finland, Baltic Sea). Mar Environ Res 119:207-221

Lenth, R (2020) emmeans: estimated marginal means, aka least-squares means. R package version 1.4.5. https://CRAN.R-project.org/ package $=$ emmeans $/$

Li J, Schiavo S, Xiangli D, Rametta G, Miglietta ML, Oliviero M, Changwen W, Manzo S (2018) Early ecotoxic effects of ZnO nanoparticle chronic exposure in Mytilus galloprovincialis revealed by transcription of apoptosis and antioxidant-related genes. Ecotoxicology 27:369-384

Liu H, He J, Chi C, Shao J (2014) Differential HSP70 expression in Mytilus coruscus under various stressors. Gene 543:166-173

Liu H, Wu J, Xu M, He J (2016) A novel biomarker for marine environmental pollution of HSP90 from Mytilus coruscus. Mar Pollut Bull 111:428-434

Livak KJ, Schmittgen TD (2001) Analysis of relative gene expression data using real-time quantitative PCR and the $2^{-\Delta \Delta} \mathrm{CT}$ method. Methods 25:402-408

Lopes-Lima M (2014) Anodonta anatina. The IUCN Red List of Threatened Species 2014: e.T155667A21400363. https://doi.org/ 10.2305/IUCN.UK.2014-1.RLTS.T155667A21400363.en. Accessed on April 12th, 2021

López-Pacheco IY, Silva-Núñez A, Salinas-Salazar C, Arévalo-Gallegos A, Lizarazo-Holguin LA, Barcelo D, Iqbal HMN, Parra-Saldívar R (2019) Anthropogenic contaminants of high concern: existence in water resources and their adverse effects. Sci Total Environ 690: $1068-1088$

Luoma SN, Rainbow PS (2005) Why is metal bioaccumulation so variable? Biodynamics as a unifying concept. Environ Sci Technol 39(7):1921-1931

Mebane CA, Schmidt TS, Miller JL, Balistrieri LS (2020) Bioaccumulation and toxicity of cadmium, copper, nickel, and zinc and their mixtures to aquatic insect communities. Environ Toxicol Chem 39(4):812-833

Milan M, Matozzo V, Pauletto M, Di Camillo B, Giacomazzo M, Boffo L, Binato G, Marin MG, Patarnello T, Bargelloni L (2016) Can ecological history influence response to pollutants? Transcriptomic analysis of Manila clam collected in different Venice lagoon areas and exposed to heavy metal. Aquat Toxicol 174:123-133

Mourgaud Y, Martinez É, Geffard A, Andral B, Stanisiere JY, Amiard JC (2002) Metallothionein concentration in the mussel Mytilus galloprovincialis as a biomarker of response to metal contamination: validation in the field. Biomarkers 7(6):479-490

Nikinmaa M, Anttila K (2019) Individual variation in aquatic toxicology: not only unwanted noise. Aquat Toxicol 207:29-33

Nugroho AP, Frank H (2011) Uptake, distribution, and bioaccumulation of copper in the freshwater mussel Anodonta anatina. Toxicol Environ Chem 93(9):1838-1850

Oliva M, De Marchi L, Cuccaro A, Casu V, Tardelli F, Monni G, Freitas R, Caliani I, Fossi MC, Fratini S, Baratti M, Pretti C (2019) Effects of copper on larvae of the marbled crab Pachygrapsus marmoratus (Decapoda, Grapsidae): toxicity test and biochemical marker responses. Comp Biochem Physiol C 223:71-77

Oliviera P, Lopes-Lima M, Machado J, Guilhermino L (2015) Comparative sensitivity of European native (Anodonta anatina) and exotic (Corbicula fluminea) bivalves to mercury. Estuar Coast Shelf Sci 167:191-198
Pérez-Morales A, Martínez-López A, Camalich-Carpizo JM (2015) Dry weight, carbon, $\mathrm{C} / \mathrm{N}$ ratio, hydrogen, and chlorophyll variation during exponential growth of selected microalgae species used in aquaculture. CICIMAR Oceánides 30(1):33-43

Perić L, Burić P (2019) The effect of copper and chlorpyrifos co-exposure on biomarkers in the marine mussel Mytilus galloprovincialis. Chemosphere 225:126-134

Potet M, Devin S, Pain-Devin S, Rousselle P, Giambérini L (2016) Integrated multi-biomarker responses in two dreissenid species following metal and thermal cross-stress. Environ Pollut 218:39-49

R Core Team (2020) R: a language and environment for statistical computing. R Foundation for Statistical Computing, Vienna https:// www.r-project.org/

Shoults-Wilson WA, Unrine JM, Rickard J, Black MC (2010) Comparison of metal concentrations in Corbicula fluminea and Elliptio hopetonensis in the Altamaha river system, Georgia, USA. Environ Toxicol Chem 29(9):2026-2033

Su C, Cui Y, Liu D, Zhang H, Baninla Y (2020) Endocrine disrupting compounds, pharmaceuticals and personal care products in the aquatic environment of China: which chemicals are the prioritized ones? Sci Total Environ 720:137652

Tsangaris C, Moschino V, Strogyloudi E, Coatu V, Ramšak A, Abu AR, Carvalho S, Felline S, Kosyan A, Lazarou Y, Hatzianestis I, Oros A, Tiganus D (2016) Biochemical biomarker responses to pollution in selected sentinel organisms across the Eastern Mediterranean and the Black Sea. Environ Sci Pollut Res 23:1789-1804

Turja R, Soirinsuo A, Budzinski H, Devier MH, Lehtonen KK (2013) Biomarker responses and accumulation of hazardous substances in mussels (Mytilus trossulus) transplanted along a pollution gradient close to an oil terminal in the Gulf of Finland (Baltic Sea). Comp. Biochem Phys C 157:80-92

U.S. EPA (1994a) Method 200.7: Determination of metals and trace elements in water and wastes by inductively coupled plasmaatomic emission spectrometry. Revision 4.4, Cincinnati, $\mathrm{OH}$

U.S. EPA (1994b) Method 200.8: Determination of trace elements in waters and wastes by inductively coupled plasma-mass spectrometry. Revision 5.4, Cincinnati, $\mathrm{OH}$

van der Oost R, Beyer J, Vermeulen NPE (2003) Fish bioaccumulation and biomarkers in environmental risk assessment: a review. Environ Toxicol Pharmacol 13:57-149

Vareda JP, Valente AJM, Durães L (2019) Assessment of heavy metal pollution from anthropogenic activities and remediation strategies: a review. J Environ Manag 246:101-118

Wang N, Mebane CA, Kunz JL, Ingersoll CG, May TW, Arnold WR, Santore RC, Augspurger T, Dwyer FJ, Barnhart CM (2009) Evaluation of acute copper toxicity to juvenile freshwater mussels (fatmucket, Lampsilis siliquoidea) in natural and reconstituted waters. Environ Toxicol Chem 28(11):2367-2377

Wang J, Tian Z, Huo Y, Yang M, Zheng X, Zhang Y (2018) Monitoring of 943 organic micropollutants in wastewater from municipal wastewater treatment plants with secondary and advanced treatment processes. J Environ Sci 67:309-317

Wang C, Yang Y, Wu N, Gao M, Tan Y (2019) Combined toxicity of pyrethroid insecticides and heavy metals: a review. Environ Chem Lett 17:1693-1706

Wickham H (2016) ggplot2: Elegant graphics for data analysis. R package version 3.3.0. Springer-Verlag, New York, United States of America. ISBN 978-3-319-24277-4. https://ggplot2.tidyverse.org/

Publisher's note Springer Nature remains neutral with regard to jurisdictional claims in published maps and institutional affiliations. 